\section{Relapsing Coombs-negative haemolytic anaemia in pregnancy with haemolytic disease in the newborn}

A rare form of acquired haemolytic anaemia is Coombs-negative haemolytic disease restricted to the period of pregnancy..$^{1-3}$ Unlike previously reported cases, in our patient transient haemolytic disease developed in the infant also, lending support to the assumption of an autoimmune mechanism.

\section{Case report}

The patient was first examined because of anaemia in March 1959 at the age of 25 in the 8th month of pregnancy. Anaemia had also been present during her first pregnancy, but no further investigations were done. During the third month of the second pregnancy weakness, palpitations, and exertional dyspnoea developed. She was pale. The liver and spleen were not palpable. Her haemoglobin was $7.0 \mathrm{~g} / \mathrm{dl}$, with $9 \%$ reticulocytes, anisocytosis, and poikilocytosis. A marrow aspirate showed considerable erythroid hyperplasia and a normal haemosiderin stain. Serum bilirubin was 8.5 $\mu \mathrm{mol} / 1(0.5 \mathrm{mg} / 100 \mathrm{ml})$, and the direct and indirect Coombs tests were negative. A healthy girl was delivered at term, and within two weeks the mother's haemoglobin rose spontaneously to $11.6 \mathrm{~g} / \mathrm{dl}$. Repeated blood counts in the next 11 years disclosed a haemoglobin level of $12 \cdot 2-13.3 \mathrm{~g} / \mathrm{d}$ (see fig). One month after delivery anaemia of $7 \mathrm{~g} / \mathrm{dl}$ was discovered in the infant. No further details of this anaemia are available, and by the age of four months the child's haemoglobin level had reverted to normal.

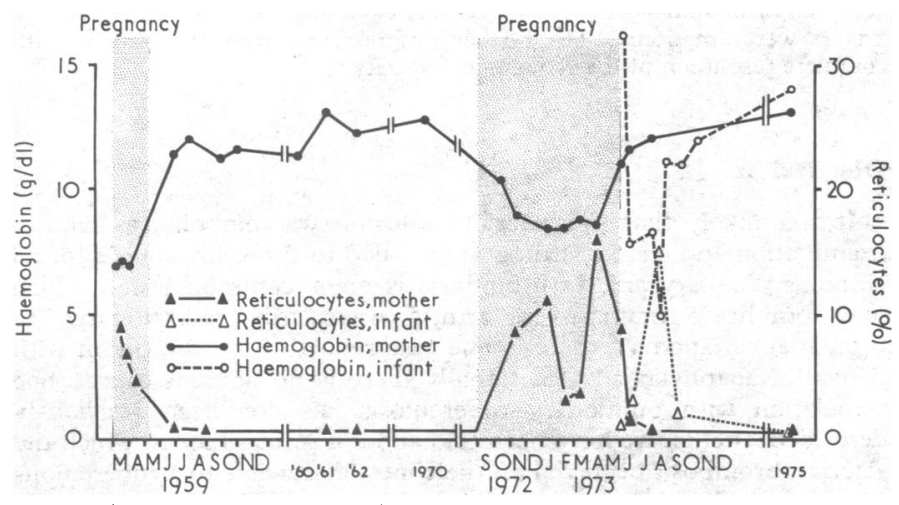

Blood counts over 11 years.

In the third month of her third pregnancy the patient's haemoglobin was $8.6 \mathrm{~g} / \mathrm{dl}$ with a reticulocyte count of $9 \cdot 2 \%$. The serum iron was $23.3 \mu \mathrm{mol} / \mathrm{l}$ $(130 \mu \mathrm{g} / 100 \mathrm{ml})$. Serum bilirubin was $22 \mu \mathrm{mol} / 1 / 1(1.3 \mathrm{mg} / 100 \mathrm{ml})$ and lactate dehydrogenase 110 units. The direct and indirect Coombs tests were negative. A Ham test, LE test, and antinuclear factor were negative. Haemoglobin electrophoresis was normal. Osmotic fragility was normal, and serum haptoglobin was $0.06 \mathrm{~g} / 1$. No medication was given, and the haemoglobin remained stable between 8.6 and $8.8 \mathrm{~g} / \mathrm{dl}$. In May 1973 an uneventful delivery of a healthy girl took place at term. The half life of ${ }^{51} \mathrm{Cr}$-labelled compatible normal donor cells received three days after delivery was uine days only. Two weeks after delivery the haemoglobin was $11.0 \mathrm{~g} / \mathrm{dl}$, and on re-examination two years later $13.2 \mathrm{~g} / \mathrm{dl}$, when the survival of ${ }^{51} \mathrm{Cr}$-labelled autologous red cells was 20 days.

The infant's haemoglobin at birth was $23.0 \mathrm{~g} / \mathrm{dl}$, but at 4 weeks had fallen to $7.8 \mathrm{~g} / \mathrm{dl}$ with $3.2 \%$ reticulocytes and a serum haptoglobin of $0.23 \mathrm{~g} / 1$ Serum iron was $20.6 \mu \mathrm{mol} / 1(115 \mu \mathrm{g} / 100 \mathrm{ml})$ and unsaturated iron binding capacity $26 \cdot 0 \mu \mathrm{mol} / \mathrm{l}(145 \mu \mathrm{g} / 100 \mathrm{ml})$. The osmotic fragility was normal, the direct and indirect Coombs tests both negative, and no isoagglutinins could be demonstrated when the mother's (AB Rh negative) and infant's ( $A R h$ positive) blood were cross matched. At 3 months the haemoglobin was $5 \cdot 3$ $\mathrm{g} / \mathrm{dl}$, with $15 \cdot 2 \%$ reticulocytes; a single transfusion of $100 \mathrm{ml}$ packed red cells was given and spontaneous recovery occurred.

\section{Comment}

Despite the absence of a positive antiglobulin reaction, the mechanism responsible for haemolysis in this patient is most probably autoimmune. Autoimmune haemolytic anaemia with several attached molecules, too low to produce a positive Coombs reaction, is now well established. ${ }^{4}$ The development of definite anaemia at the age of 4 weeks in our patient's babies with a reticulocytosis of $15 \%$ and a high transferrin saturation indicates a haemolytic mechanism which was most probably caused by placental transfer of maternal antibodies. This is unlikely to have been due to a virus infection, but transplacental migration of fetal erythrocytes may have stimulated maternal autosensitised immune-competent cells to increase their autoantibody production. ${ }^{5}$

${ }^{1}$ Jankelowtiz, T, Eckerling, B, and Joshua, H, South African Medical fournal, 1960, 34, 911.

2 Mallarme, J, et al, Nouvelle Revue Francaise d'Hematologie, 1965, 5, 756.

${ }^{3}$ Craig, G A, and Turner, R L, British Medical fournal, 1955, 1, 1003.

4 Gilliland, B C, Baxter, E, and Evans, R S, New England fournal of Medicine, 1971, 285, 252.

${ }^{5}$ Chaplin, H, et al, British fournal of Haematology, 1973, 24, 219.

Departments of Haematology and Paediatrics, Hadassah University Hospital, Jerusalem, Israel

A ELDOR, $M D$, instructor in medicine

$S$ YATZIV, $M D$, lecturer in paediatrics

C HERSHKO, MD, senior lecturer in medicine

\section{Plasma zinc in acute starvation}

Zinc is present in many tissues of the body and is essential for normal growth and metabolism by virtue of its role in nucleic acid and protein synthesis and its presence in metalloenzymes. Zinc deficiency causes failure of growth, anorexia, loss of taste, and gonadal atrophy. Pascoe et $a l^{1}$ found that the plasma zinc of fasting rats fell in a step-wise fashion, whereas Quarterman ${ }^{2}$ found raised concentrations in the first two days of starvation. Spencer and Samachson ${ }^{3}$ found no decrease in plasma zinc concentrations in humans undergoing therapeutic starvation.

\section{Subjects, methods, and results}

Four men aged between 27 and 40 and five women aged between 25-30 years submitted to a 72-hour period of starvation. Two of the women were taking oral contraceptives and continued to do so throughout the study; no other medication was permitted. The subjects were allowed only unlimited water throughout the 72 hours and they continued with their normal occupation. Blood samples were taken with a Yale Microlance needle and a B-D Sterile Plastipak syringe. The blood was stored in a heparinised glass container before estimating the plasma zinc concentration by the atomic absorption spectrophotometric method. ${ }^{4}$ Control blood samples were taken at $11 \mathrm{am}$ after an overnight fast and samples were taken at 11 am daily after 24,48 , and 72 hours' starvation.

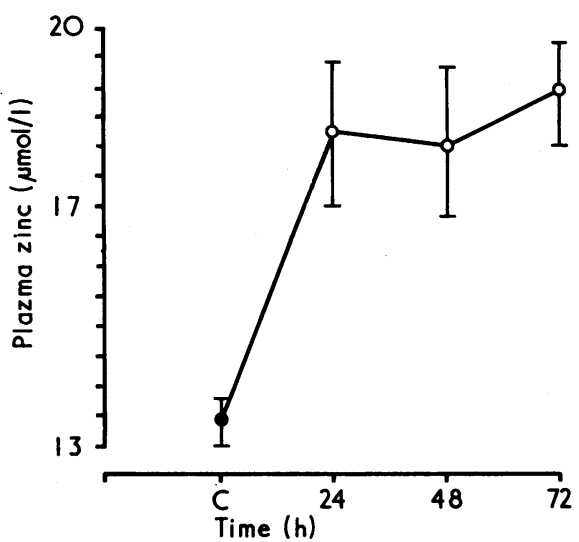

Mean ( \pm SEM) plasma zinc concentrations in 9 subjects during 72 hours' starvation.

Conversion: SI to traditional units-Zinc $1 \mu \mathrm{mol} / 1 \approx 0.15 \mu \mathrm{g} / 100 \mathrm{ml}$. 
The results are shown in the fig. The paired $t$ test comparing the control concentration with the concentrations at 24,48 , and 72 hours showed significantly higher concentrations of plasma zinc for each time during the starvation period $(P<0.025,<0.0125$, and $<0.0025$ respectively). The mean plasma concentrations $( \pm S E M)$ were $13.4 \pm 0.6 \mu \mathrm{mol} / 1(88.2 \pm 3.9 \mu \mathrm{g} / 100$ $\mathrm{ml}$ ) at the control reading and $18.2+1.2,18.0 \pm 1.2$, and $18.8+0.9$ $\mu \mathrm{mol} / 1(119 \cdot 7+7 \cdot 8,118 \cdot 4 \pm 7 \cdot 8$, and $123.6 \pm 5.9 \mu \mathrm{g} / 100 \mathrm{ml})$ at 24,48 , and 72 hours respectively. There were individual variations but no subject failed to show a rise.

\section{Discussion}

Plasma zinc concentrations vary diurnally and fall after a meal. This experiment was designed to try to eliminate these factors. Oral contraceptives lower plasma zinc concentrations, but the subjects in our study taking these preparations had unremarkable control values. They continued to take them throughout and the changes in their plasma zinc concentrations were similar to those of the other subjects. We do not know the origin of the zinc that raised the plasma concentrations in our subjects, but Spencer and Samachson ${ }^{3}$ suggest that the zinc in the zincuria of prolonged starvation comes from the liver.

R W Henry was holding a Royal Victoria Hospital Clinical Research Fellowship when this work was carried out. Margaret E Elmes was supported by funds from the Eastern Health and Social Services Board.

1 Pascoe, E, Arslanian, M, and Reinhold, J G, Pahlavi Medical fournal, $1971,2,29$.

${ }^{2}$ Quarterman, J, 1974, personal communication.

${ }^{3}$ Spencer, $\mathrm{H}$, and Samachson, J, in Trace Element Metabolism in Animals, ed C F Mills, p 312. Edinburgh, Livingstone, 1970.

${ }^{4}$ Peaston, R T, Medical Laboratory Technology, 1973, 30, 249.

Department of Medicine, Queen's University of Belfast, Northern Ireland

R W HENRY, MB, MRCP, clinical research fellow (present appointment: senior registrar, Belfast City Hospital, and senior tutor, Department of Medicine, Queen's University, Belfast)

MARGARET E ELMES, MB, PHD, research assistant

\section{Axillary artery occlusion and pulmonary tuberculosis}

Axillary artery thrombosis may complicate various conditions, but its association with pulmonary tuberculosis has not to our knowledge been previously reported.

\section{Case report}

A 45-year-old male Sikh was admitted with a ten-day history of productive cough and fever, together with pain of gradually increasing severity in the right arm. He was a non-smoker. On examination his temperature was $38^{\circ} \mathrm{C}$, pulse $90 / \mathrm{min}$, and blood pressure $120 / 90 \mathrm{~mm} \mathrm{Hg}$. The right hand was cold and cyanosed and all arterial pulses of the right upper limb were absent. No bruits were audible in the neck. There were signs of consolidation of the right upper lobe and this was confirmed by a chest radiograph (figure). An electrocardiogram was normal and urine testing showed no glycosuria. He was thought to have axillary artery thrombosis and pneumonia, possibly with an underlying bronchial carcinoma. Treatment was with heparin, analgesics, and antibiotics-initially ampicillin and later cephalothin and gentamicin. He remained febrile but the axillary and brachial pulses returned over the next few days and ischaemic changes were limited to dry gangrene of the finger tips.

One week after admission he deteriorated, becoming semicomatose with tachycardia, tachypnoea, hypotension, cyanosis, a rise in the jugular venous pressure, and crepitations in both lung fields. Despite the clinical appearance of heart failure the chest radiograph was essentially unchanged and an electrocardiogram showed no appreciable abnormality. Investigations showed that he had a haemoglobin of $4 \mathrm{~g} / \mathrm{dl}$ and a blood glucose of $19.4 \mathrm{mmol} / \mathrm{l}$ $(350 \mathrm{mg} / 100 \mathrm{ml})$. He was therefore transfused with packed cells and given insulin, oxygen, frusemide, digoxin, and hydrocortisone. He was thought to have a septicaemia due either to tuberculosis or a Gram-positive organism; the antibiotic regimen was therefore changed to rifampicin, isoniazid, streptomycin, and cloxacillin.

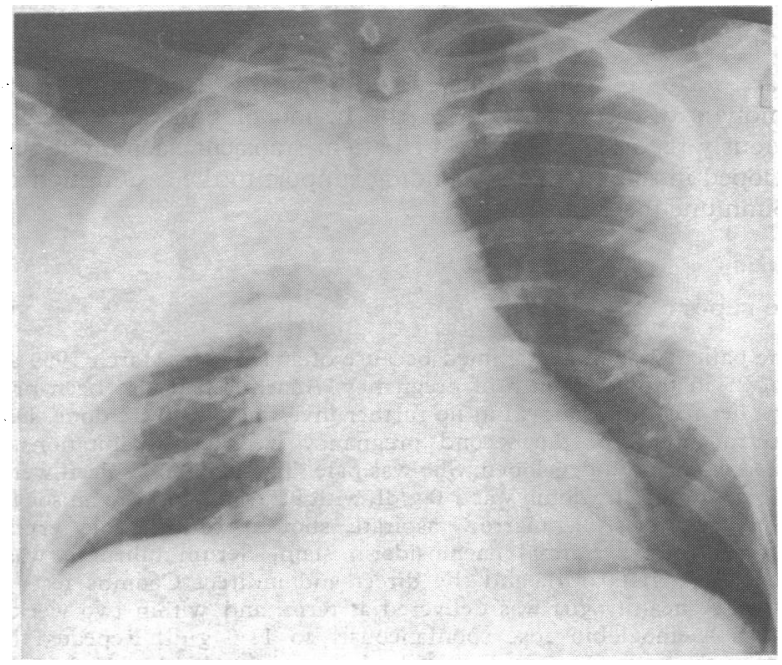

Chest radiograph showing consolidation in right upper lobe.

He improved dramatically over the next 24 hours, becoming fully conscious and afebrile. Sputa were subsequently found to contain Mycobacterium tuberculosis; antituberculous therapy was continued and diabetic control achieved with oral agents. Six weeks after admission the tips of several fingers were amputated. His further progress has been satisfactory, with complete resolution of the radiological opacity.

\section{Discussion}

It is unlikely that the arterial occlusion was embolic, as clinical examination and electrocardiography failed to show any source for an embolus. Axillary artery thrombosis is an uncommon lesion which may complicate trauma to the arm, a cervical rib, ${ }^{1}$ radiotherapy, ${ }^{2}$ or bronchial carcinoma ${ }^{3}$; there is one case report of its asscoaition with penicillin anaphylaxis. ${ }^{4}$ Occasionally there is no obvious cause. The association with pulmonary tuberculosis has not been previously described, though we have been told about a similar case in which the arterial thrombosis occurred on the contralateral side to a tuberculous pneumonia. Possibly a generalised clotting tendency is present in tuberculosis, but this aspect has reieived little attention in published work. There was no evidence of a cervical rib or aneurysm of the axillary artery, but latent diabetes mellitus may have been a factor in our case. ${ }^{5}$ The diagnosis of pulmonary tuberculosis was considered because of his race and because, as a life-long non-smoker, carcinoma of the bronchus was unlikely. He was in extremis and antituberculous therapy was started before bacteriological proof had been obtained.

Since treated tuberculosis has a good prognosis, this condition should be excluded in all patients who present with an arterial occlusion in the arm and an abnormal chest radiograph.

We wish to thank Mr A Clain and Dr J F Riordan for permission to report this case.

1 Wood, P B, British fournal of Surgery, 1973, 60, 29.

2 Mavor, G E, et al, British fournal of Surgery, 1973, 60, 983.

${ }^{3}$ Knox, W G, Nay, M R, and Blumenthal, J, American fournal of Surgery, $1966,111,752$.

${ }^{4}$ Andrejevic, M, Srpski Arhiv za Celokupno Lekarstvo, 1964, 92, 793.

5 Goldenberg, S, et al, Diabetes, 1959, 8, 261.

Dudley Road Hospital, Birmingham B18 7 QH

GEOFFREY NICHOLSON, BSC, MRCP, medical registrar

A K SACHDEVA, FRCS ED, surgical registrar (now senior registrar in surgery, Luton and Dunstable Hospital, Beds) 